\title{
DNA damage, salivary cortisol levels, and cognitive parameters in a nursing team
}

\author{
Iranez Bortolotto ${ }^{\mathrm{a}, \mathrm{b}}$, Ana Paula Scherer de Brum ${ }^{\mathrm{a}, \mathrm{c}}$, Temenouga Nikolova Guecheva ${ }^{\mathrm{b}}$, \\ Larissa Milano de Souza $^{\mathrm{b}}$, Ana Ligia Lia de Paula-Ramos ${ }^{\mathrm{b}}$, Cristiano Trindade ${ }^{\mathrm{b}, \mathrm{d}, *}$, \\ Angelica Rosat Consiglio ${ }^{\mathrm{a}, \mathrm{b}, \mathrm{*} * \mathrm{*}}$ \\ a Programa de Pós-Graduação em Enfermagem, Universidade Federal do Rio Grande do Sul (UFRGS), Porto Alegre, RS, Brazil \\ ${ }^{\mathrm{b}}$ Departamento de Biofísica, Instituto de Biociências, Universidade Federal do Rio Grande do Sul (UFRGS), RS, Brazil \\ ${ }^{\mathrm{c}}$ Universidade do Oeste de Santa Catarina (UNOESC), SC, Brazil \\ ${ }^{\mathrm{d}}$ Facultad de Ciencias Básicas y Biomédicas, Universidad Simón Bolívar, Barranquilla, Colombia
}

\section{A R T I C L E I N F O}

\section{Keywords:}

Comet assay

Cortisol

Genotoxicity

Micronucleus test

Occupational health

\begin{abstract}
A B S T R A C T
In a cross-sectional study of women in a nursing team at a university hospital in southern Brazil, we studied DNA damage, salivary cortisol levels, and cognition. DNA damage was measured in blood leukocytes with the comet assay and the micronucleus test. Salivary cortisol levels were determined upon waking, 30 min later, and at bedtime. Cognition was evaluated according to the Stroop, Digit span and Word span tests. Cortisol levels on waking up were associated negatively with the number of years the employee worked at the institution and positively with the DNA damage in comet assay. Cognitive scores were lower when the cortisol levels were low at awakening and high at bedtime; and were associated positively with educational level. Cortisol status may influence overall health as well as essential work skills, such as attention.
\end{abstract}

\section{Introduction}

Hospital nursing staff must be 'multi-task'; their jobs demand constant attention, focused memory, and decision making, prioritizing patients' most immediate care needs. Even well-prepared nurses may experience high levels of occupational stress [1], due to factors such as work overload, work intensity, interpersonal conflicts, long shifts, night shifts, the psychological impact of patients' conditions, excessive standardization of procedures, and lack of recognition of effort [2-7]. In Brazil, interpersonal conflicts within the health staff are one of the main stressors in nursing teams $[2,8,9]$. The sense of lack of control and the lack of social support are additional sources of stress [10,11].

Working memory, memory retrieval, divided attention, decision making, and, ultimately, task performance are affected by stress. Brain regions mediating cognitive functions, such as the hippocampus, amygdala, and prefrontal cortex, can be affected by stress effects on dendritic arborization, dendritic spines, and synapse numbers [12].
Studies in animal models and humans indicate that short-term exposure to stress hormones (e.g., cortisol, norepinephrine, epinephrine) can cause DNA damage and interfere with cell-cycle regulation and DNA repair $[13,14]$. A single stressful event can cause DNA damage in specific brain sites in rats; DNA damage in the hippocampus was still present one week after immobilization stress [15]. DNA damage was observed in the hippocampus in chronically stressed male (but not female) rats [16].

Stress hormones can reduce DNA repair capacity and interfere with cell-cycle regulation by suppressing p53 levels $[17,18]$ and affecting DNA repair proteins such as the Chk1 and Chk2 kinases [13], resulting in an imbalance between DNA damage and repair and compromising maintenance of DNA integrity [19,20]. Jenkins et al. [21] suggested that cortisol (in humans) can increase MDM2 activation, resulting in loss of p53 function. Reeder et al. [22] indicated that stress hormones can result in DNA damage, activation of ATR, and upregulation of the cyclin-dependent kinase inhibitor p21. As a major target of p53 activity, p21 mediates cell cycle arrest in response to DNA damage. The comet

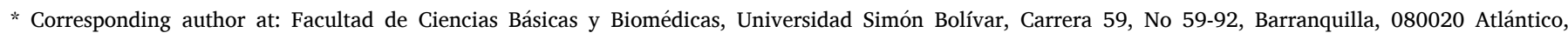
Colombia.

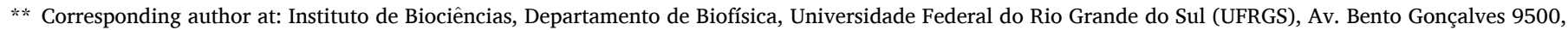
Porto Alegre, RS, CEP 91501-970, Brazil.

E-mail addresses: cristiano.trindade@unisimonbolivar.edu.co (C. Trindade), arconsig@ufrgs.br (A.R. Consiglio).
} 
assay and cytokinesis-block micronucleus (CBMN) assay are routinely used as genotoxicity biomarkers in human biomonitoring (reviewed in [23]).

Nursing-team stress has been evaluated worldwide with reporting scales [1] and, less frequently, with biomarkers such as cortisol. Among physicians, self-reported pre-shift stress was positively associated with salivary cortisol [24]. Elevated levels of cortisol are associated with biological aging, and a cross-sectional study in older adults showed that serum cortisol is related to frailty [25]. The cortisol awakening response (CAR) has been associated with psychosocial and health issues [26-30]. The absence of CAR, or an atypical CAR, such as a flattened response, has been negatively associated with health in acute and chronic psychosocial stress [31], subclinical disease [32], and increased mortality in breast cancer patients [33].

In addition to occupational factors, nursing staff may face other adverse exposures: physical (e.g., ionizing radiation [IR]), chemical (e. g., antineoplastic agents), and psychosocial (e.g., stress) [34]. Radioprotection is well-established and legislated; occupational stress protection, much less so. In the first phase of our study, we found that occupational IR exposure (below the established safety limit) did not correlate with a nursing team's DNA strand breaks or MN frequency [35], although other risk factors (such as stress) may also have roles.

The cortisol-releasing pattern may be altered because of stress, thus affecting cognitive skills. Therefore, the goal of this study was to examine molecular/hormonal stress parameters in relation to DNA damage and alterations in skills/behaviors that may affect nursing care; the subjects were members of a nursing team, with or without IR exposure, working in four different hospital units.

\section{Materials and methods}

\subsection{Subjects}

This cross-sectional study ( $\mathrm{n}=78$ ) was conducted in 2013 at the University Hospital in Porto Alegre, Rio Grande do Sul, Brazil, and included members of the nursing team not exposed to IR, working in the Ambulatory $(\mathrm{n}=31)$ and Midwifery $(\mathrm{n}=10)$ Units, and occupationally exposed to IR in the Hemodynamic $(n=16)$ and Radiology $(n=21)$ Units. All subjects were women, mean age $=45.2 \pm 8.8$ years (Table 1 ).

Overall, $5 \%$ of the subjects were smokers (1-10 cigarettes per day),

Table 1

Characteristics of the Nursing Team studied in a Hospital of Southern Brazil .

\begin{tabular}{llll}
\hline Characteristics & Mean \pm SD & N & $\%$ \\
\hline Age (years) & $45.21 \pm 8.8$ & 78 & - \\
Gender (female) & - & 78 & 100 \\
Work at the Institution (years) & $16.05 \pm 10.8$ & 78 & - \\
Exposure to IR & & & \\
$\quad$ Yes & - & 37 & 47.4 \\
No & & 41 & 52.6 \\
Smoker & - & & \\
Yes & & 4 & 5.1 \\
No & - & 74 & 94.9 \\
Alcohol & & & \\
Yes & & 28 & 35.9 \\
No & - & 50 & 64.1 \\
Physical Exercise & & & \\
Yes & & 21 & 26.9 \\
No & - & 57 & 73.1 \\
BMI & & 21 & \\
18.5-24.9 & & 33 & 42.3 \\
$25.0-29.9$ & - & 30 & 38.5 \\
30 and Above & & 44 & 56.4 \\
Medicines & & 34 & 43.6 \\
Yes & & & \\
No & & & \\
\hline
\end{tabular}

* Data collected from questionnaire. IR - Ionizing Radiation, BMI - Body Mass Index.
$36 \%$ consumed alcohol (only socially, 1-5 days in a month), $73 \%$ did not practice physical exercise three or more times per week, and $56 \%$ used some medicine. The types of alcoholic beverages consumed were wine and beer. Among those who practiced physical activities, these were walking and gym exercise at least $6 \mathrm{~h}$ prior to blood sampling. The mean length of employment at the institution was $16 \pm 10.8$ years. Briefly, the Ambulatory nursing team provides direct assistance and educational activities to patients and their families and performs home visits. The Midwifery Unit is part of the service assisting women during pregnancy, childbirth, and postpartum. In the Radiology and Hemodynamic Units, there is occupational exposure to IR (activities in conventional $\mathrm{x}$-rays and computed tomography) in addition to regular nursing activities. As a measure of radioprotection, personal protective equipment is used in these two units, and rotation (weekly or biweekly) of the staff is implemented. The exposed nursing team received doses lower than the annual dose allowed by law (according to personal dosimeters) and did not exhibit increased DNA damage relative to the nonexposed nursing team, as described in the first part of this study [35]. The nurses in all four units had $6 \mathrm{~h}$ work shift at the Institution and $6-8 \mathrm{~h}$ of sleep. Nurses taking corticoids and/or working on night shifts were excluded from the study. Also excluded were those who were pregnant, had previously received cancer chemotherapy, or had been exposed as patients to IR due to diagnostic (last three months) or therapeutic (last year) procedures. The study protocol was in accordance with the Declaration of Helsinki for research involving human subjects and was approved by the ethics committee of the hospital (\#11-0603); all participants gave written informed consent.

\subsection{Salivary cortisol}

Saliva was collected and kept in Salivette ${ }^{\circledR}$ devices. Salivary cortisol was determined at three time points: at awakening ( Cort $_{\text {Zero }}$ ), $30 \mathrm{~min}$ after waking up ( Cort $_{30}$ ), and at bedtime ( Cort $_{\mathrm{N}}$ ) during working days. Oral and written orientation was given, such as avoiding food, alcohol, smoking, teeth brushing, or intense physical exercise before saliva collection. Salivary cortisol (Roche kit) was measured using electrochemiluminescence detection (Siemens) at the Clinical Pathology Laboratory of the hospital, and laboratory staff was blind to the experimental conditions of the study. The reference values informed by the Laboratory for the Salivary cortisol were $<19.7 \mathrm{nmol} / \mathrm{L}$ in the morning $(06.00-10.00 \mathrm{~h})$ and $<9.7 \mathrm{nmol} / \mathrm{L}$ at night $(23.00-00.30 \mathrm{~h})$. After the analyses, samples were stored at $-20^{\circ} \mathrm{C}$. CAR (CAR $=\mathrm{Cort}_{30}-$ Cort $_{\text {zero }}$ ), area under the curve between the moment of awakening and bedtime, and the slope (b) of the line measured between cortisol at bedtime $\left(\operatorname{Cort}_{\mathrm{N}}, \mathrm{t}_{\mathrm{N}}\right)$ and at awakening (Cort $\mathrm{zero}, \mathrm{t}_{\mathrm{zero}}$ ) were calculated. The slope " $\mathrm{b}$ " is usually negative because $\mathrm{b}=\left(\operatorname{Cort}_{\mathrm{N}}-\right.$ Cort $_{\mathrm{zero}} / \mathrm{t}_{\mathrm{N}}-$ $\mathrm{t}_{\mathrm{zero}}$ ), Cort $_{\mathrm{N}}<$ Cort $_{\mathrm{zero}}$, and $\mathrm{t}_{\mathrm{N}}$ (bedtime) $>\mathrm{t}_{\mathrm{zero}}$ (awakening time).

\subsection{Blood sampling}

Peripheral blood samples of the subjects were collected into heparinized tubes, on Wednesdays, from 10 a.m. to $4 \mathrm{pm}$, from January to May 2013. All blood samples were coded, chilled at $4{ }^{\circ} \mathrm{C}$, and processed within $2 \mathrm{~h}$ after collection. The alkaline comet assay in whole blood samples was conducted immediately after blood transportation.

\subsection{Comet assay}

The alkaline comet assay [36] used in this study followed the general guidelines of Singh et al. [37] and Fairbairn et al. [38] with some modifications. All steps were conducted under indirect light and the slides were coded and analyzed without knowledge of sample identity. A sample of lymphocytes isolated with Histopaque $1077(50 \mu \mathrm{L})$ was mixed with $0.5 \%$ low-melting-point agarose (Invitrogen), $300 \mu \mathrm{L}$, at 37 ${ }^{\circ} \mathrm{C}$. This mixture was placed on slides previously coated with $1 \%$ normal-melting-point agarose (Cambrex Bio Science Rockland) at $60^{\circ} \mathrm{C}$. 
The agarose layers were covered with cover slips, which were removed after the gel solidified. The slides were immersed overnight in lysis solution (2.5 M NaCl, $100 \mathrm{mM}$ EDTA, and $10 \mathrm{mM}$ Tris; $\mathrm{pH}$ 10.0-10.5; with freshly added $1 \%$ Triton X-100 and $10 \%$ DMSO) at $4{ }^{\circ} \mathrm{C}$ in the dark. Blood collected from healthy volunteers was used periodically for preparing of negative and positive controls. Cells treated with hydrogen peroxide $(150 \mu \mathrm{M}, 5 \mathrm{~min})$ on the slide at $4{ }^{\circ} \mathrm{C}$ were used as positive controls.

The coverslips were carefully removed and the slides were placed in alkaline buffer for $30 \mathrm{~min}$ at $4{ }^{\circ} \mathrm{C}(300 \mathrm{mM} \mathrm{NaOH}, 1 \mathrm{mM} \mathrm{EDTA}$; $\mathrm{pH}>13)$ to unwind the DNA. Electrophoresis was performed at $0.7 \mathrm{~V} / \mathrm{cm}, 300 \mathrm{~mA}$ for $30 \mathrm{~min}$ at $4{ }^{\circ} \mathrm{C}$. Positive and negative controls were included in each electrophoresis run. Slides were neutralized ( $0.4 \mathrm{M}$ Tris, $\mathrm{pH} 7.5$ ), washed in double-distilled water, stained by a silver-staining protocol [39], and analyzed with an optical microscope. From two replicate slides, 100 cells were selected and analyzed for DNA migration. Cells were visually scored according to tail length into five classes: class 0 , undamaged; class 1 , tail shorter than head (nucleus) diameter ; class 2 , tail length 1-2 $\times$ head diameter; class 3 , tail longer than $2 \times$ head diameter; and class 4 , comets with almost all DNA in the tail (comets with no heads). The damage index (DI) was calculated according to the visual classification system [39]. DI values ranged from 0 (completely undamaged: 100 cells of class 0 ) to 400 (with maximum damage: 100 cells of class 4). For statistical analysis, we used the mean values of DI and damage frequency (DF). The DF (\%) was calculated based on the number of tailed (damaged) versus tailless (undamaged) cells [36,39, 40].

\subsection{CBMN test}

The CBMN assay [41] was conducted using the cytochalasin B technique [42] and following the recommendations from the International Collaborative Project on Micronucleus Frequency in Human Populations (HUMN Project). Cultures were prepared in Falcon 3033 tubes in duplicate using heparinized whole blood $(0.5 \mathrm{~mL})$ and Gibco PB-MAX Karyotyping Medium (Life Technologies, Grand Island, New York, USA) supplemented with $10 \%$ fetal bovine serum. Lymphocytes were incubated at $37^{\circ} \mathrm{C}, 5 \% \mathrm{CO}_{2}$. Two parallel cultures were set in tubes (Falcon 3033) for each sample. At $44 \mathrm{~h}$ after initiation, cells were blocked with cytochalasin B (Sigma-Aldrich, St. Louis, MO), final concentration $=4 \mu \mathrm{g} / \mathrm{mL}$. Positive (mitomycin C, $0.20 \mu \mathrm{g} / \mathrm{mL}$ ) and negative (DMSO) controls were run in parallel. The cells were harvested at $72 \mathrm{~h}$, treated with hypotonic solution $(0.075 \mathrm{M} \mathrm{KCl})$, immediately centrifuged, and fixed three times with methanol/acetic acid (3:1). The fixed cells were dropped onto humidified slides. Air-dried slides were stained with Giemsa for $10 \mathrm{~min}$. A minimum of 500 cells were scored for calculation of the nuclear division index (NDI). For each culture, 1000 binucleated cells were scored blindly using optical microscope following the scoring criteria outlined by the HUMN Project $[41,43]$ and the number of cells with micronucleus per 1000 binucleated cells was recorded.

\subsection{Cognitive tests}

The Stroop test was applied to measure selective attention; the digit and word span were used to measure memory [44]. The tests were applied by previously trained examiners in a silent room. Briefly, the Stroop test consists of three sets of tests, each in a time frame of $45 \mathrm{~s}$ and maximum score of 100 per sheet: the person must first read colored words that match with the colors of the ink in random order (Stroop_word); second, name the color of colored X's (Stroop_color); and third, name the incongruous color of the written color word (Stroop_color/word), for example, "blue", in the word "red", printed in blue. There is an increase in reaction time in the last task because of the interference of the word on the incongruent color, and it varies according to age, gender, and educational level [45-47]. The digit and word span are components of the Wechsler scale that is commonly used to access declarative and working memory. In the digit span test, the subject repeats a crescent sequence of digits (maximum 14) said by the examiner. In the word span test, the subject is asked to repeat a list of (10) words said previously by the examiner.

\subsection{Data analysis}

The quantitative variables were previously tested for homogeneity of variance (Kolmogorov-Smirnov test). If they did not present homogeneity of the variance, the variables were subjected to a mathematical transformation (such as square root). The variables cortisol level, damage index (ID), damage frequency (FD), and BMI were submitted to Student's $t$-test for independent groups, comparing the IR-exposed vs. non-exposed groups. The variables square root of the micronucleus frequency, Stroop, and Span were subjected to one-way ANOVA to compare the IR-exposed vs non-exposed groups, considering age as a covariate.

Categorical variables were analyzed using the chi-square test. Differences between groups were considered significant when $\mathrm{P}<0.05$. The Pearson correlation test was used to select the variables to be included in a multivariate linear regression analysis. When $\mathrm{P}=0.25$ or lower, those variables were included as factors in a multivariate linear regression model and tested again for significance; those factors (variables) that continued to have their $\mathrm{P}=0.25$ or lower remained in the model. The linear regression model was considered significant when $\mathrm{P}<$ 0.05 .

\section{Results}

Salivary cortisol levels from the Radiology, Hemodynamics, Ambulatory, and Midwifery Unit nursing teams at three time points (i.e., at awakening, $30 \mathrm{~min}$ after waking up, and at bedtime) are presented in Fig.1. There was no significant difference between the groups in relation to the mean cortisol levels at these time points, although the Midwifery Unit presented an altered curve pattern without the expected increase 30 min after waking. The Midwifery Unit also presented elevated DI in relation to the other Units, as shown in the first part of this study [35]. There were no differences in cortisol levels or cognitive scores in relation to occupational IR exposure (Table 2).

For 57 participants (73\%), Cort $_{\text {zero }}$ or Cort $_{30}$ was $>19.7 \mathrm{nmol} / \mathrm{L}$, the upper limit of the healthy reference value. The numbers of participants above this limit did not differ among the four Units (data not shown) or in relation to IR exposure (Table 2). The laboratory that performed the analysis does not establish lower limits for salivary cortisol. Using the same determination method, other laboratories consider $3.86 \mathrm{nmol} / \mathrm{L}$ as a lower limit for morning salivary cortisol. Nine of the participants presented Cort $_{\text {zero }}$ or $\mathrm{Cort}_{30}$ below this value. Their mean age was $49.8 \pm$ 8.8 and seven of them had worked at the Institution 17-35 years. For eight individuals, BMI was $>28$ and seven did not practice physical exercise. Most studies that evaluate stress based on salivary cortisol do

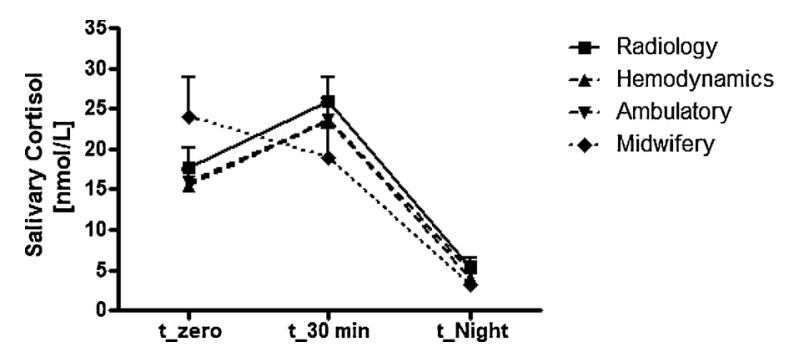

Fig. 1. Salivary cortisol levels. t_zero $=$ waking up time; $t_{-} 30 \mathrm{~min}=30 \mathrm{~min}$ after waking up; t_night: bedtime. Data are expressed as mean \pm SEM, Two-way ANOVA. Ambulatory $(\mathrm{n}=31)$, Midwifery $(\mathrm{n}=10)$, Hemodynamic $(\mathrm{n}=16)$ and Radiology $(\mathrm{n}=21)$. 
Table 2

Values of Salivary Cortisol and Cognitive Scores in the Nursing Team according to the Occupational Exposure to Ionizing Radiation (IR)*.

\begin{tabular}{|c|c|c|}
\hline & $\begin{array}{l}\text { Exposed to IR ( } \mathrm{n}= \\
37)\end{array}$ & $\begin{array}{l}\text { Not Exposed to IR }(n= \\
41)\end{array}$ \\
\hline $\operatorname{Cort}_{\text {zero }}(\mathrm{nmol} / \mathrm{L})$ & $15.59 \pm 6.96$ & $17.89 \pm 11.2$ \\
\hline $\operatorname{Cort}_{30}(\mathrm{nmol} / \mathrm{L})$ & $23.5 \pm 9.55$ & $22.48 \pm 12.62$ \\
\hline $\operatorname{Cort}_{\mathrm{N}}(\mathrm{nmol} / \mathrm{L})$ & $4.76 \pm 4.81$ & $4.52 \pm 4.96$ \\
\hline $\begin{array}{l}\text { Cort }_{\text {zero }} \text { or } \text { Cort }_{30}>19.7 \\
\text { nmol/L } \\
\%(\mathrm{n})\end{array}$ & $75.7 \%(28)$ & $70.7 \%(29)$ \\
\hline Stroop_word & $88.22 \pm 15.44$ & $84.95 \pm 14.53$ \\
\hline Stroop_color & $62.19 \pm 10.85$ & $61.46 \pm 9.18$ \\
\hline Stroop_word/color & $33.97 \pm 8.56$ & $34.59 \pm 8.70$ \\
\hline Digit Span & $7.94 \pm 2.99$ & $7.7 \pm 3.24$ \\
\hline Word Span & $6.02 \pm 1.23$ & $5.75 \pm 1.04$ \\
\hline Age (years) & $44.97 \pm 8.65$ & $45.41 \pm 8.90$ \\
\hline
\end{tabular}

" Exposed to IR - Radiology and Hemodynamics; Not Exposed - Ambulatory and Midwifery. Cort ${ }_{\text {zero }}$ : cortisol soon after awakening; Cort $_{30}$ : cortisol $30 \mathrm{~min}$ after waking up; Cort $_{\mathrm{N}}$ : cortisol at bedtime. Data presented as Mean \pm SD. Cortisol levels were compared in Student's $t$-test and cognitive scores were subjected to One-way ANOVA considering age as covariable. The number of nurses with Cort $_{\text {zero }}$ or Cort $_{30}>19.7 \mathrm{nmol} / \mathrm{L}$ was compared in $\chi 2$ test.

not use a reference standard as a cutoff point, but rather rely on the levels to compare groups under different conditions.

DNA DI did not differ in relation to occupational IR exposure, as reported in the first part of this study [35], or between participants with normal weight, overweight, or obesity (Fig. 2). DI did not correlate with BMI, but correlated positively with Cort $_{\text {zero }}$ (Fig. 3). The number of years working at the Institution correlated negatively with DI and Cort zero (Fig. 3). The historical laboratory mean \pm SD values of comet assay DI for women with the same age range were $48.7 \pm 29.2$ [48]. The mean values of MN frequency showed no significant difference in relation to IR exposure ( $2.4 \pm 1.96$ per 1000 binucleated cells, exposed, vs $2.4 \pm 1.83$, non-exposed) [35], and did not differ from the MN frequency in healthy controls used in previous studies by the laboratory [49]. MN did not correlate with BMI or Cort zero. $_{\text {. }}$

Among the participants who used medicines, $75 \%$ presented morning cortisol levels $>19.7 \mathrm{nmol} / \mathrm{L}$, while among those who did not use medicines, the rate was $71 \%$. The medicines used were antihypertensive drugs, analgesics, antidiabetic drugs, cholesterol reducing drugs, thyroid hormones, antidepressants, anti-inflammatory drugs, contraceptives, and antibiotics.

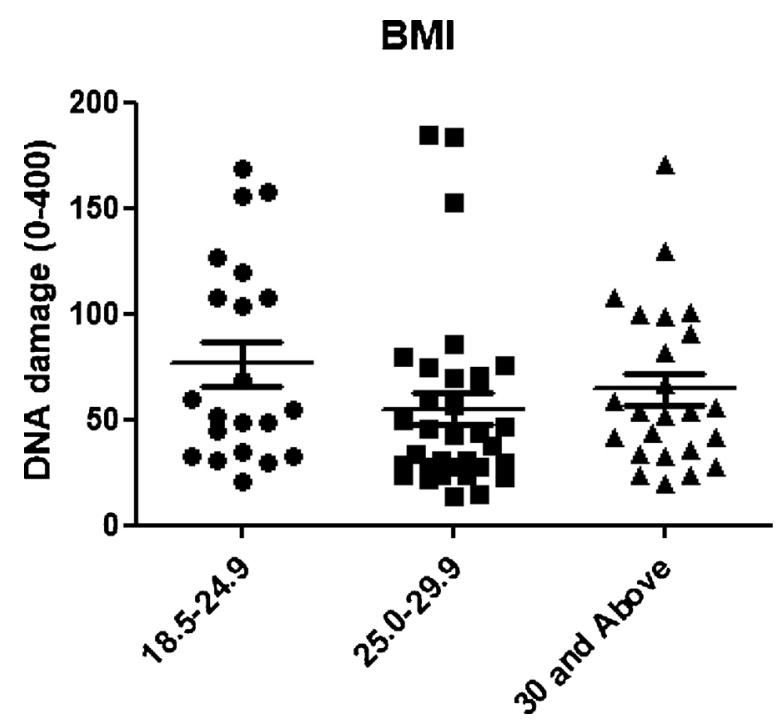

Fig. 2. DNA Damage Index in peripheral blood mononuclear cells (PBMC) in relation to BMI. Data presented as mean \pm SEM, One-way ANOVA.
Nine participants (three in the group exposed to IR and six not exposed) used contraceptives. The mean value of the cortisol levels in the group using contraception did not differ from those of age-matched controls (sub-group of the total sample).

The correlations among the variables studied, i.e., cognitive functions, DNA damage, salivary cortisol, and number of years at the institution, were assessed in the total nursing-team sample. There were no differences between the variables studied in relation to alcohol consumption, smoking status, or physical activity.

\subsection{DNA damage linear regression model}

Pearson correlation values between DNA damage and cortisol or occupational radiation exposure profile are presented in Table 3. Only correlations with $\mathrm{P}<0.25$ were considered for linear regression purposes. The results showed that DI was positively correlated with Cort and negatively correlated with the number of years at the institution.

The variables that remained in the linear regression model for DI were Cort ${ }_{\text {zero }}$ and number of years at the institution, adjusted for age and years of education. The proposed linear regression model for DI (P = 0.017 and $\mathrm{R}^{2}=0.151$ ) is as follows: $\mathrm{DI}=94.34-3.64$ (years of education) +0.653 (Cort zero $)-1.40$ (years at the Institution). Hence, $15.1 \%$ of DI variation is explained by years of education, levels of Cort zero, and number of years at the institution. Numbers of years of education and years at the institution decreased DI, whereas higher levels of Cort increased DI. The variables that remained in the MN linear regression model were $\mathrm{Cort}_{30}$ and years of education, $\mathrm{MN}=3.6-0.13$ (years of education) $-0.026\left(\mathrm{Cort}_{30}\right)+0.025$ (age), but it lost significance when adjusted for age $\left(\mathrm{P}=0.07\right.$ and $\left.\mathrm{R}^{2}=0.092\right)$.

\subsection{Cognitive score linear regression model}

Pearson correlation values between cognitive scores and DNA damage are presented in Table 4 and between cognitive scores and cortisol profile are presented in Table 5.

The following variables remained in the linear regression model for

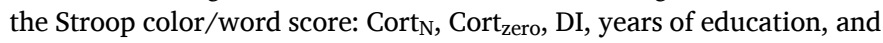
age. The proposed linear regression model for the Stroop color/word score $\left(P=0.001\right.$ and $\left.R^{2}=0.255\right)$ is as follows: Stroop color/word score $=46.4+0.378$ (years of education) $-0.27\left(\operatorname{Cort}_{\mathrm{N}}\right)+0.142\left(\right.$ Cort $\left._{\text {zero }}\right)-$ 0.052 (DI) -0.332 (age). According to this model, years of education, Cort $_{\mathrm{N}}$, Cort score variation: higher education and Cort $_{\text {zero }}$ increased the score, whereas higher Cort $_{N}$, DI, and aging decreased it. The variables that remained in the digit span score linear regression model were MN, DI, years of education, and age. The proposed linear regression model for the digit span score $\left(\mathrm{P}=0.001\right.$ and $\left.\mathrm{R}^{2}=0.248\right)$ is as follows: Digit Span score $=2.05-0.2061(\mathrm{MN})-0.012(\mathrm{DI})+0.475$ (years of education) + 0.012 (age). $24.8 \%$ of digit span score variation is attributed to MN, DI, education, and age. The digit span score increases as education and age increase, and it decreases as MN and DI increase.

\subsection{Cortisol regression model}

Cortisol profile (Table 6) was tested for age, education, and number of years at the institution. The variable "years at the institution" were then included in the linear regression model for the cortisol profile.

The proposed linear regression model for $\operatorname{Cort}_{\text {zero }}\left(P=0.002\right.$ and $\mathrm{R}^{2}$ $=0.115$ ) is as follows: Cort ${ }_{\text {zero }}=21.6-0.296$ (years at the Institution). According to the model, $11.5 \%$ of the Cort explained by employee time at the institution: Cort $_{\text {zero }}$ decreased as time worked increased. The association with the number of years at the institution was stronger than with age, which is why the former was included in the model instead of the latter. 

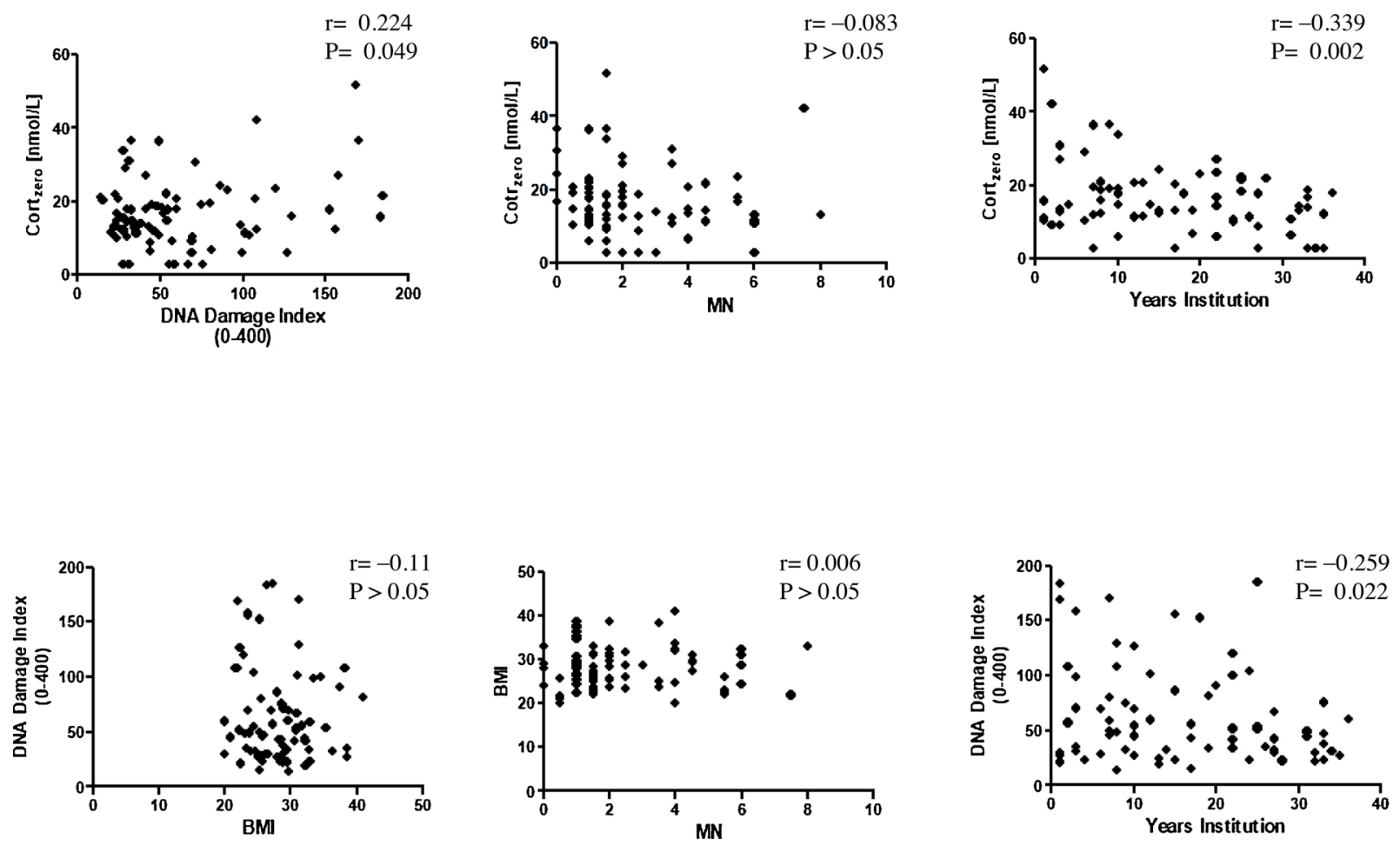

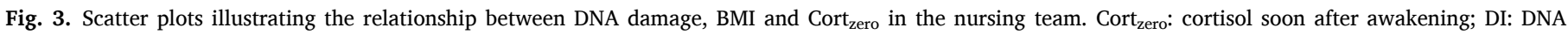
damage index, MN: micronucleus, BMI: Body Mass Index. Pearson correlation, $\mathrm{n}=78$.

Table 3

Correlation of DNA Damage with Cortisol Profile and occupational exposure parameters in nursing team.

\begin{tabular}{|c|c|c|c|c|c|c|}
\hline & DNA DI $(\mathrm{n}=78)$ & & DNA DF $(\mathrm{n}=78)$ & & Micronucleus $(\mathrm{n}=77)$ & \\
\hline & $\mathrm{r}$ & $\mathrm{p}$ & $\mathrm{r}$ & $\mathrm{p}$ & $\mathrm{r}$ & $\mathrm{p}$ \\
\hline Cort $_{\text {zero }}$ & 0.224 & 0.049 & 0.153 & 0.182 & -0.083 & ns \\
\hline Cort $_{30}$ & 0.089 & ns & 0.126 & ns & -0.181 & 0.116 \\
\hline $\operatorname{Cort}_{N}$ & -0.050 & ns & -0.052 & ns & 0.122 & ns \\
\hline CAR & -0.089 & $\mathrm{~ns}$ & -0.002 & ns & -0.098 & ns \\
\hline AUC & 0.007 & $\mathrm{~ns}$ & 0.035 & ns & -0.039 & ns \\
\hline $\mathrm{b}$ & -0.018 & ns & -0.018 & ns & 0.161 & 0.161 \\
\hline Age & -0.121 & ns & -0.110 & ns & 0.185 & 0.107 \\
\hline Education (years) & -0.197 & 0.085 & -0.242 & 0.033 & -0.220 & 0.054 \\
\hline Years at the Institution & -0.259 & 0.022 & -0.246 & 0.030 & 0.198 & 0.084 \\
\hline Years of IR & -0.176 & 0.124 & -0.205 & 0.072 & 0.063 & ns \\
\hline
\end{tabular}

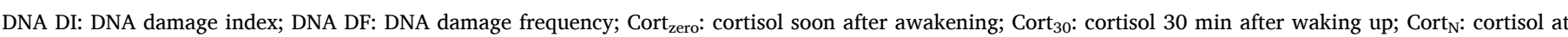

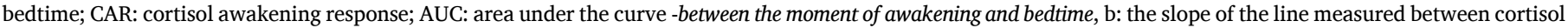
at awakening and bedtime; Years of IR: years of ionizing radiation occupational exposure. r: Pearson correlation coefficient, ns: $P>0.25$.

Table 4

Correlation between DNA Damage and Cognitive Scores.

\begin{tabular}{|c|c|c|c|c|c|c|}
\hline & \multicolumn{2}{|l|}{$\begin{array}{l}\text { DNA DI } \\
\mathrm{n}=78\end{array}$} & \multicolumn{2}{|l|}{$\begin{array}{l}\text { DNA DF } \\
\mathrm{n}=78\end{array}$} & \multicolumn{2}{|c|}{$\begin{array}{l}\text { Micronucleus } \\
\mathrm{n}=77\end{array}$} \\
\hline & $\mathrm{r}$ & $\mathrm{p}$ & $\mathrm{r}$ & $\mathrm{p}$ & $\mathrm{r}$ & $\mathrm{p}$ \\
\hline Stroop_word & -0.170 & 0.136 & -0.155 & 0.174 & -0.307 & 0.007 \\
\hline Stroop_color & -0.244 & 0.031 & -0.258 & 0.023 & -0.284 & 0.012 \\
\hline Stroop_word/color & -0.204 & 0.074 & -0.248 & 0.029 & -0.098 & ns \\
\hline Digit Span & -0.245 & 0.030 & -0.265 & 0.019 & -0.215 & 0.060 \\
\hline Word Span & 0.015 & ns & 0.045 & ns & -0.133 & 0.250 \\
\hline
\end{tabular}

DNA DI: DNA damage index; DNA DF: DNA damage frequency; r: Pearson correlation coefficient, ns: $P>0.25$.

\section{Discussion}

We analyzed the relationship between cortisol levels, IR exposure, DNA damage, and some cognitive skills that are essential for the nursing profession, such as attention and memory. Overall, the results suggest that Cort $_{\text {zero }}$ levels in the nursing team decreased as number of years worked at the institution increased. Higher DNA damage detected in the comet assay and MN test correlated with lower (worse) Digit Span scores, while better Stroop color/word scores related to increase in Cort $_{\text {zero }}$ and years of education.

Cortisol, a catabolic hormone, released in the blood by the adrenal cortex, maintains the blood glucose level during the day so as to provide energy to the brain and neuromuscular system. In addition to its normal function, cortisol has a key role in the stress response, providing energy to cope with the stress condition. Its levels rise within minutes after the stressful event and remain elevated for several hours. This cortisol increase is adaptive in the short term (eustress). According to the general adaptation syndrome (GAS) postulated by Hans Selye (1946), a threephase physiologic stress response follows: first, the alarm reaction (adrenal release of epinephrine and glucocorticoid production) helps to restore homeostasis; second, the resistance phase, and third, the exhaustion phase, where the adaptive response stops and a negative 
Table 5

Correlation of Cognitive Scores with Cortisol Profile and occupational exposure parameters in nursing team.

\begin{tabular}{|c|c|c|c|c|c|c|c|c|c|c|}
\hline & \multicolumn{2}{|c|}{ Stroop_word } & \multicolumn{2}{|c|}{ Stroop_color } & \multicolumn{2}{|c|}{ Stroop_word/color } & \multicolumn{2}{|c|}{ Digit Span } & \multicolumn{2}{|c|}{ Word Span } \\
\hline & $\mathrm{r}$ & $\mathrm{p}$ & $\mathrm{r}$ & $\mathrm{p}$ & $\mathrm{r}$ & $\mathrm{p}$ & $\mathrm{r}$ & $\mathrm{p}$ & $\mathrm{r}$ & $\mathrm{p}$ \\
\hline Cort $_{\text {Zero }}$ & 0.047 & $\mathrm{~ns}$ & 0.073 & ns & 0.164 & 0.152 & 0.107 & ns & -0.052 & ns \\
\hline Cort $_{30}$ & 0.061 & ns & 0.114 & ns & 0.036 & ns & 0.057 & ns & 0.022 & ns \\
\hline $\operatorname{Cort}_{\mathrm{N}}$ & -0.144 & 0.207 & -0.221 & 0.051 & -0.136 & 0.237 & 0.123 & ns & -0.158 & 0.166 \\
\hline CAR & 0.020 & $\mathrm{~ns}$ & 0.047 & ns & -0.091 & ns & -0.030 & $\mathrm{~ns}$ & 0.059 & ns \\
\hline AUC & 0.025 & ns & 0.027 & ns & -0.009 & ns & 0.090 & ns & -0.121 & ns \\
\hline $\mathrm{b}$ & -0.144 & 0.209 & -0.195 & 0.087 & -0.189 & 0.098 & 0.027 & ns & 0.030 & ns \\
\hline Age & -0.179 & 0.117 & -0.240 & 0.034 & -0.373 & 0.001 & -0.051 & ns & -0.250 & 0.027 \\
\hline Education (years) & 0.248 & 0.029 & 0.273 & 0.016 & 0.223 & 0.050 & 0.435 & 0.000 & 0.179 & 0.117 \\
\hline Years Institution & -0.107 & ns & -0.106 & ns & -0.177 & 0.120 & 0.040 & ns & -0.163 & 0.154 \\
\hline Years of IR & -0.076 & $\mathrm{~ns}$ & -0.174 & 0.128 & -0.215 & 0.058 & 0.112 & $\mathrm{~ns}$ & -0.011 & ns \\
\hline
\end{tabular}

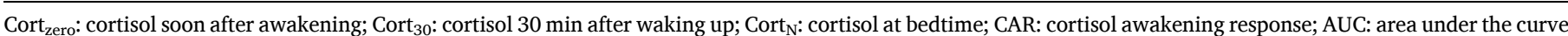

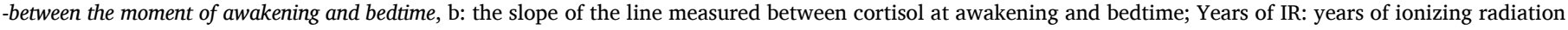
occupational exposure. $\mathrm{n}=78$. $\mathrm{r}$ : Pearson correlation coefficient, $\mathrm{ns}: P>0.25$.

Table 6

Correlation of Cortisol with Age and years at the Institution in the nursing team.

\begin{tabular}{|c|c|c|c|c|c|c|c|c|c|c|c|c|}
\hline & \multicolumn{2}{|l|}{ Cort $_{\text {Zero }}$} & \multicolumn{2}{|l|}{ Cort $_{30}$} & \multicolumn{2}{|l|}{$\operatorname{Cort}_{N}$} & \multicolumn{2}{|l|}{ AUC } & \multicolumn{2}{|l|}{ CAR } & \multicolumn{2}{|l|}{$\mathrm{b}$} \\
\hline & $\mathrm{r}$ & $\mathrm{p}$ & $\mathrm{r}$ & $\mathrm{p}$ & $\mathrm{r}$ & $\mathrm{p}$ & $\mathrm{r}$ & $\mathrm{p}$ & $\mathrm{r}$ & $\mathrm{p}$ & $\mathrm{r}$ & $\mathrm{p}$ \\
\hline Age & -0.243 & 0.032 & -0.197 & 0.083 & 0.047 & ns & -0.103 & ns & 0.006 & ns & 0.099 & ns \\
\hline Education (years) & 0.012 & ns & -0.024 & ns & 0.016 & ns & 0.023 & ns & 0.840 & ns & -0.084 & ns \\
\hline Years at the Institution & -0.339 & 0.002 & -0.104 & ns & 0.072 & ns & -0.012 & ns & 0.164 & 0.153 & 0.210 & 0.065 \\
\hline Years of IR & -0.177 & 0.120 & 0.006 & ns & 0.084 & ns & 0.013 & ns & 0.140 & 0.222 & 0.133 & 0.245 \\
\hline
\end{tabular}

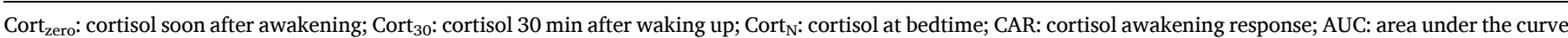

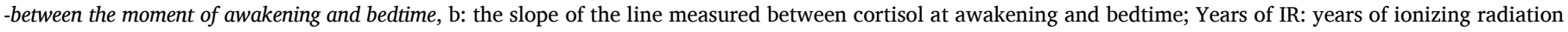
occupational exposure. $\mathrm{n}=78$. $\mathrm{r}$ : Pearson correlation coefficient, $\mathrm{ns}: P>0.25$.

state begins [50]. The effort to maintain a balance (allostasis) becomes inefficient and turns to overload [51]. The altered cortisol pattern then signals chronic stress or chronic fatigue. Repeated cortisol secretion in the chronic stress response induces cortisol dysfunction as a result of cortisol depletion, impaired corticotropin-releasing hormone function, glucocorticoid receptor (GR) resistance, etc. (reviewed in [52]). Cortisol binding to the mineralocorticoid receptor, as a result of extreme surges and/or resistance of the GR, promotes proinflammatory effects [52].

Stress mediators can have both protective and damaging effects, depending on the secretion time-course. Physiologic cortisol release has a typical circadian profile, with highest level at waking up in the morning and declining thereafter. The magnitude of this decline depends on cortisol levels either at waking up or at bedtime. This fluctuation prepares the individual for daily demands. In response to stress, the magnitude and/or the dynamic of cortisol release may be altered [53-55]. Higher morning and bedtime cortisol levels have been related to chronic stress. A flattened profile (i.e., low cortisol levels in the morning or high cortisol levels at night) has been linked to higher chronic fatigue symptoms and poorer metabolic health (abdominal obesity, hypertension, high triglycerides and fasting glucose, insulin resistance), and may be an indicator of hypoactive hypothalamic-pituitary-adrenal (HPA) activation [56]. High cortisol levels before bedtime have been linked to inappropriate stress recovery [31]. This circadian pattern may also be a presentation of an allostatic load subtype characterized by a failure to exhibit an expected biomarker's circadian cycle or recovery after a stressor [32]. We observed no significant differences in the studied parameters in relation to occupational exposure to IR. Instead, the nurses working in the Midwifery Unit presented significantly increased DNA strand breaks in relation to the other Units [35] and also an altered cortisol curve pattern (Fig. 1). Most of the nurses in the study presented elevated morning cortisol levels (considering the $19.7 \mathrm{nmol} / \mathrm{L}$ as an upper limit), which could indicate stressful conditions. Therefore, we decided to perform linear regression analysis, to predict, according to the model, the weights by which the variables in the regression equation contribute to outcome variation.

The DNA damage linear regression model showed that high levels of Cort ${ }_{\text {zero }}$ were associated with high DNA DI in the comet assay. The mechanisms by which the chronic stress condition (indicated by the elevated cortisol) can contribute to accumulation of DNA damage could be elevation of direct damage to DNA, resulting from oxidative stress induction and/or inhibition of the repair of lesions formed by intermediates of endogenous metabolism or exogenous genotoxic agents. In agreement with this, exposure to stress hormones (such as cortisol, norepinephrine, epinephrine) has been found to elevate DNA damage and decrease DNA repair [13]. DNA damage induced by cortisol in breast cancer cells was reduced by incubation with an iNOS inhibitor, suggesting involvement of damaging reactive nitrogen species [13]. A relationship between cortisol and oxidative DNA damage was also observed in patients with post-traumatic stress disorder [57]. Cort ${ }_{\mathrm{zero}}$, measured immediately after waking up, has been linked to expectancies of the day [58]. Thus, we suggest that increased DI could be partially linked to allostatic load. It has been estimated that each human cell sustains approximately 70,000 DNA lesions per day, mainly oxidative damage [59]; therefore, repair inhibition could lead to mutations or epigenetic alterations.

The comet assay detects damage and repair at the single cell level. The DI is a measure of DNA damage caused by a recent exposure (still can be repaired), as opposed to the permanent chromosomal damage detected by the $\mathrm{MN}$ test, i.e., clastogenesis and aneugenesis. Oxidative damage in human peripheral blood cells is actively repaired by base excision repair (BER) [60]. DNA strand breaks are formed during this process, as repair intermediates after the excision step. The subsequent polymerization and ligation steps are limited by the low deoxyribonucleotide pools in non-cycling lymphocytes [61], and the DNA strand-break intermediates can be detected in the comet assay. Thus, the increased DI observed in our study, in association with increased Cortzero, could result from direct strand breaks and/or active repair of oxidative damage to DNA bases. On the other hand, chronic exposure to high concentration of genotoxic agents could lead to a toxic condition, 
with inhibition of DNA metabolism and decrease in DI. Such decreased DI was associated with oxidative stress and DNA repair inhibition in blood samples of breast cancer [48] and chronic obstructive pulmonary disease [62] patients. In the breast cancer patients, initial induction of superoxide dismutase (SOD) was accompanied by an increase in DI in blood cells. However, in patients with extreme SOD induction (indicating oxidative stress), DNA damage observed in the comet assay decreased to levels even lower than in healthy controls. This is explained by inhibition of DNA metabolism and elimination of highly damaged cells by apoptosis [48]. We did not evaluate DNA repair and cannot confirm that a similar toxic condition resulting from adverse chronic exposure can explain the negative correlation between DI and number of years at the institution found in our study.

Conversely, the cortisol response prepares the individual for a high demanding situation. Despite the "cost" (i.e., increase in DNA damage) of the action, higher Cort $_{\text {zero }}$ contributed to better cognitive scores. However, a chronic exposure is harmful, triggering diseases and cognitive deficits [63-65]. In this study, low Cort $_{\text {zero }}$ and high Cort $_{\mathrm{N}}$ correlated with worse cognitive scores measured by the Stroop word/color score.

In humans, increased cortisol levels after a psychosocial stimulus have been associated with hippocampus deactivation [29]. The hippocampus takes part not only in memory processing but also in inhibiting the HPA axis as part of a neural circuitry relevant to stress [12,29, 66-68]. The dynamic of cortisol release has been related to cognitive scores: the higher the CAR, the better the cognitive scores; and an attenuated CAR has been linked to poorer overall cognitive performance [69]. A better episodic memory, but not working memory, has been linked to higher CAR. Moreover, higher waking up cortisol has also been related to better working memory [70]. A reduced CAR has been found in situations such as caregiving burden [71] and burnout [72], and it has been suggested that this CAR reduction is not beneficial to hippocampus-mediated memory function [70].

As expected, a better cognitive performance was found among those with increased educational levels. An impaired digit span score (as an index of working memory score) is expected to be associated with altered cortisol profile. However, our results did not show correlation. Instead, decreased digit span score was associated with higher DNA damage, MN and DI. The acute [15] and chronic [16] stresses induce DNA damage in rats' hippocampus. Increased cortisol levels, as a consequence of occupational stress could lead to DNA repair inhibition, accumulation of DNA damage and apoptosis induction. The elevated DNA damage in blood cells in our study could be an indicator of systemic adverse effects of chronic stress, which can also affect memory, evaluated by the digit span score. Thus, the current data reinforce that an altered pattern in the cortisol release dynamics is related to attention and to the ability to discriminate between two concomitant stimuli, which are essential functions for professional nursing activities. Much attention and concentration is needed, for example, during medication preparation [73], whereas impaired attention or momentary distraction may increase the likelihood of errors. Stressors such as perceived overload or high workload have been associated with dispensing errors among pharmacists $[1,74,75]$.

Although MN is already known to increase with aging and cognitive scores are known to depend on education and age, the other contributions relating to DNA damage and cortisol profile have not yet been described in the context of nursing. Aside from working conditions, personal and sociodemographic characteristics have an important role in stress. Although younger professionals could be more vulnerable to experience stress at work, possibly related to immaturity and decreased coping skills [2,76,77], we did find a stronger association other than between age and cortisol. With longer time at the institution, Cort $_{\text {zero }}$ was lower. Although aging also contributed to decrease cortisol, a much stronger association was found with number of years at the institution than with aging. As long as younger and older employees share similar tasks, this result should be interpreted as some kind of adaptation or accommodation from the older employees that makes them spend less energy for the expectations of the coming working day. Moreover, low cortisol levels in the morning, high levels at night, and other alterations in cortisol-releasing pattern could indicate cortisol dysfunction, which could occur as a result of chronic stress and exhaustion throughout the time of employment.

In Brazil, the nursing team is composed of both nurses and nursing assistants. The former requires university education, whereas the latter requires only a high school education. A higher level of education was related to both less DNA damage (DI and MN) and better cognitive results. Protective effects of education may relate to better understanding of risks and to better job conditions and categories.

Younger workers were linked to better cognitive scores on the Stroop color/word score, but not on the digit span score. Age has been linked to increased DNA damage, measured by micronucleus frequency [78].

One of the challenges in epidemiology is designing the control group. Many individuals have a morbid condition or take medication, possibly affecting release of cortisol; chronic disease can trigger stress and increase release of cortisol. Also, stress could trigger chronic diseases. These factors appear concurrently and we cannot distinguish cause and effect. Of the participants, $81 \%$ presented BMI $>24.9$, characteristic of overweight or obesity. Stress and obesity are connected in many ways; stress can increase consumption of high- calorie foods, stimulate release of the hormones leptin and ghrelin, decrease physical activity, and disturb sleep (reviewed in [79]).

In the first part of this study [35], no relationship was found between occupationally IR exposure and DNA damage in blood leucocytes. Here, we found no difference between cortisol levels in participants occupationally exposed or not exposed to IR. Nonetheless, the relationship between high IR doses and DNA damage is well known and the legislation for the safety limit is carefully applied. Although there are well-established regulations for occupational IR risks, occupational stress is harder to measure and regulate.

\section{Implications and future perspectives}

The finding that DNA damage is related to cortisol profile (present study) and not to occupational exposure to IR [35] raises some issues. When studying occupational radiation effects, evaluation of stress levels should also be performed. Altered levels of cortisol could influence DNA damage otherwise attributed to radiation exposure. Identifying the best stress biomarkers and the most vulnerable persons (sentinel individuals) can help in formulating an effective workplace program for stress prevention. Patient health depends not only on the skills of the care team but also on the management of the institution.

\section{Limitations}

The influence of additional stress sources outside the work place was not evaluated. Although the use of corticoids was an exclusion criterion, the use of other medications (i.e., antidepressants, antihypertensive drugs, contraceptives, analgesics, anti-inflammatory drugs, thyroid hormones) may have affected the cortisol profile, DNA damage, or cognition. Actual errors (e.g., medication errors), were not measured, even if a relationship between altered cortisol patterns and cognition was established.

\section{Authors contribution}

I. Bortolotto: instructed saliva collection, acquired data in Cognitive tests, Comet assay and MN assay. A.P.S. de Brum: instructed saliva collection, acquired data in Cognitive tests. T.N. Guecheva: acquired data in Comet Assay, analyzed and interpreted data, wrote and revised the manuscript. L.M. de Souza: acquired data in Comet Assay. A.L.L. de Paula-Ramos: designed and supervised the study. C. Trindade: acquired and analyzed data in MN assay; revised and edited the 
manuscript. A.R. Consiglio: conceived, designed and supervised the whole study, analyzed and interpreted data, wrote and revised the manuscript. All authors read and approved the final manuscript.

\section{Funding}

This work was supported by Coordination for the Improvement of Higher Education Personnel (CAPES) of Brazil (project no: CAPES-8064/ 14-8), Research and Events Incentive Fund (FIPE) of Hospital de Clínicas de Porto Alegre (project no: FIPE/HCPA-110603) and Support Foundation for the Federal University of Rio Grande do Sul (FAURGS) (project no: FAURGS/Radioanalysis-3504).

\section{Declaration of Competing Interest}

None.

\section{References}

[1] Workplace Stress: a Collective Challenge, International Labour Organization (ILO), 2016. www.ilo.org/safeday.

[2] D.T. Costa, M. do C.F. Martins, Estresse em profissionais de enfermagem: impacto do conflito no grupo e do poder do médico/ Stress in nursing professionals: impact of conflict in the group and the power of the doctor, Rev. Esc. Enferm. USP. 45 (2011) 1191-1198, https://doi.org/10.1590/S0080-62342011000500023.

[3] R.M.G.S. Coutrin, P.R. Freua, C.M. Guimarães, Estresse em enfermagem: uma análise do conhecimento produzido na litertura brasileira no período de 1982 a 2001/ Nursing stress: an analysis of knowledge production in brazilian literature Bases, Bireme.Br. 12 (4) (2003) 486-494.

[4] S.M. de, C. Farias, O.Lde C. Teixeira, W. Moreira, M.A.F. de Oliveira, M.O. Pereira, Caracterização dos sintomas físicos de estresse na equipe de pronto atendimento/ Characterization of physical symptoms of stress in the emergency care team, Rev. Esc. Enferm. USP. 45 (2011) 722-729, https://doi.org/10.1590/S008062342011000300025.

[5] M.M. Theme Filha, M.Ade S. Costa, M.C.R. Guilam, M.M. Theme Filha, M.Ade S. Costa, M.C.R. Guilam, Occupational stress and self-rated health among nurses, Rev. Lat. Enfermagem 21 (2013) 475-483, https://doi.org/10.1590/S010411692013000200002.

[6] Rda S. Hanzelmann, J.P. Passos, Imagens e representações da enfermagem acerca do stress e sua influência na atividade laboral/ Nursing images and representations about stress and its influence on work activity, Rev. Esc. Enferm. USP. 44 (2010) 694-701, https://doi.org/10.1590/S0080-62342010000300020.

[7] V.A. Mininel, P.C.P. Baptista, V.E.A. Felli, Cargas psíquicas e processos de desgaste em trabalhadores de enfermagem de hospitais universitários brasileiros/ Psychic loads and wear processes in nursing workers at Brazilian university hospitals, Rev. Lat. Am. Enfermagem. 19 (2011) 340-347, https://doi.org/10.1590/S010411692011000200016.

[8] B. Paschoalini, M.M. Oliveira, M.C. Frigério, A.L.R.P. Dias, F.H. dos Santos, Cognitive and emotional effects of occupational stress in nursing professionals, Acta Paul. Enferm. 21 (2008) 487-492, https://doi.org/10.1590/S010321002008000300017.

[9] T.L. Simons, R.S. Peterson, Task conflict and relationship conflict in top management teams: the pivotal role of intragroup trust, J. Appl. Psychol. 85 (2000) 102-111, https://doi.org/10.1093/eurpub/ckq039.

[10] S.I. Lindeberg, M. Rosvall, B. Choi, C. Canivet, S.-O. Isacsson, R. Karasek, P.O. Ostergren, Psychosocial working conditions and exhaustion in a working population sample of Swedish middle-aged men and women, Eur. J. Public Health. 21 (2011) 190-196, https://doi.org/10.1093/eurpub/ckq039.

[11] M.Rde O. Negromonte, T.C.C.F. de Araujo, Impact of the clinical management of pain: evaluation of stress and coping among health professionals, Rev. Lat. Am. Enfermagem. 19 (2011) 238-244, https://doi.org/10.1590/S010411692011000200003.

[12] B.S. McEwen, P.J. Gianaros, Stress- and allostasis-induced brain plasticity, Annu. Rev. Med. 62 (2011) 431-445, https://doi.org/10.1146/annurev-med-052209100430.

[13] M.S. Flint, A. Baum, W.H. Chambers, F.J. Jenkins, Induction of DNA damage, alteration of DNA repair and transcriptional activation by stress hormones, Psychoneuroendocrinology. 32 (2007) 470-479, https://doi.org/10.1016/j. psyneuen.2007.02.013.

[14] M.S. Flint, G. Kim, B.L. Hood, N.W. Bateman, N.A. Stewart, T.P. Conrads, Stress hormones mediate drug resistance to paclitaxel in human breast cancer cells through a CDK-1-dependent pathway, Psychoneuroendocrinology. 34 (2009) 1533-1541, https://doi.org/10.1016/j.psyneuen.2009.05.008.

[15] A.R. Consiglio, A.L.L.P. Ramos, J.A.P. Henriques, J.N. Picada, DNA brain damage after stress in rats, Prog. Neuro Psychopharmacol. Biol. Psychiatry 34 (2010) 652-656, https://doi.org/10.1016/j.pnpbp.2010.03.004.

[16] C.G. Noschang, L.F. Pettenuzzo, E. von Pozzer Toigo, A.C. Andreazza, R. Krolow, A. Fachin, M.C. Ávila, D. Arcego, L.M. Crema, L.A. Diehl, C.A. Gonçalvez, D. Vendite, C. Dalmaz, Sex-specific differences on caffeine consumption and chronic stress-induced anxiety-like behavior and DNA breaks in the hippocampus,
Pharmacol. Biochem. Behav. 94 (2009) 63-69, https://doi.org/10.1016/j. pbb.2009.07.007.

[17] M.R. Hara, J.J. Kovacs, E.J. Whalen, S. Rajagopal, R.T. Strachan, W. Grant, A. J. Towers, B. Williams, C.M. Lam, K. Xiao, others A stress response pathway regulates DNA damage through beta, Nature 2 (2011) 349-353, https://doi.org/ 10.1038/nature10368.

[18] M.R. Hara, B.D. Sachs, M.G. Caron, R.J. Lefkowitz, Pharmacological blockade of a $\beta 2$ AR- $\beta$-arrestin- 1 signaling cascade prevents the accumulation of DNA damage in a behavioral stress model, Cell Cycle 12 (2013) 219-224, https://doi.org/10.4161/ cc. 23368.

[19] S. Jalal, J.N. Earley, J.J. Turchi, DNA repair: from genome maintenance to biomarker and therapeutic target, Clin. Cancer Res. 17 (2011) 6973-6984, https:// doi.org/10.1158/1078-0432.CCR-11-0761.

[20] T.B. Kryston, A.B. Georgiev, P. Pissis, A.G. Georgakilas, Role of oxidative stress and DNA damage in human carcinogenesis, Mutat. Res. Fundam. Mol. Mech. Mutagen 711 (2011) 193-201, https://doi.org/10.1016/j.mrfmmm.2010.12.016.

[21] F.J. Jenkins, V.H. Bennett, D.H. Bovbjerg, Effects on DNA damage and/or repair processes as biological mechanisms linking psychological stress to cancer risk, J. Appl. Biobehav. Res. 19 (2014) 1-18, https://doi.org/10.1111/jabr.12019. Effects.

[22] A. Reeder, M. Attar, L. Nazario, C. Bathula, A. Zhang, D. Hochbaum, E. Roy, K. L. Cooper, Stress hormones reduce the efficacy of paclitaxel in triple negative breast cancer through induction of DNA damage, Br. J. Cancer 112 (2015) 1461-1470, https://doi.org/10.1038/bjc.2015.133.

[23] C. Ladeira, L. Smajdova, The use of genotoxicity biomarkers in molecular epidemiology: applications in environmental, occupational and dietary studies, AIMS Genet 4 (2017) 166-191, https://doi.org/10.3934/genet.2017.3.166.

[24] B.B. Arnetz, P. Lewalski, J. Arnetz, K. Breejen, K. Przyklenk, Examining selfreported and biological stress and near misses among Emergency Medicine residents: a single-centre cross-sectional assessment in the USA, BMJ Open 7 (2017) e016479, https://doi.org/10.1136/bmjopen-2017-016479.

[25] D. Marcos-Pérez, M. Sánchez-Flores, A. Maseda, L. Lorenzo-López, J.C. MillánCalenti, E. Pásaro, B. Laffon, V. Valdiglesias, Serum cortisol but not oxidative stress biomarkers are related to frailty: results of a cross-sectional study in Spanish older adults, J. Toxicol. Environ. Heal. - Part A Curr. Issues 82 (2019) 815-825, https:// doi.org/10.1080/15287394.2019.1654639.

[26] A. Clow, L. Thorn, P. Evans, F. Hucklebridge, The awakening cortisol response: methodological issues and significance, Stress 7 (2004) 29-37, https://doi.org/ 10.1080/10253890410001667205.

[27] U.M. Nater, E. Maloney, R.S. Boneva, B.M. Gurbaxani, J.-M. Lin, J.F. Jones, W. C. Reeves, C. Heim, Attenuated morning salivary cortisol concentrations in a population-based study of persons with chronic fatigue syndrome and well controls, J. Clin. Endocrinol. Metab. 93 (2008) 703-709, https://doi.org/10.1210/ jc. 2007-1747.

[28] J.C. Pruessner, O.T. Wolf, D.H. Hellhammer, A. Buske-Kirschbaum, K. von Auer, S. Jobst, F. Kaspers, C. Kirschbaum, Free cortisol levels after awakening: a reliable biological marker for the assessment of adrenocortical activity, Life Sci. 61 (1997) 2539-2549, https://doi.org/10.1016/s0024-3205(97)01008-4.

[29] J.C. Pruessner, K. Dedovic, M. Pruessner, C. Lord, C. Buss, L. Collins, A. Dagher, S. J. Lupien, Stress regulation in the central nervous system: evidence from structural and functional neuroimaging studies in human populations - 2008 Curt Richter Award Winner, Psychoneuroendocrinology 35 (2010) 179-191, https://doi.org/ 10.1016/j.psyneuen.2009.02.016.

[30] A. Steptoe, J. Siegrist, C. Kirschbaum, M. Marmot, Effort-reward imbalance, overcommitment, and measures of cortisol and blood pressure over the working day, Psychosom. Med. 66 (2004) 323-329, https://doi.org/10.1097/01. psy.0000126198.67070.72.

[31] E.K. Adam, M. Kumari, Assessing salivary cortisol in large-scale, epidemiological research, Psychoneuroendocrinology 34 (2009) 1423-1436, https://doi.org/ 10.1016/j.psyneuen.2009.06.011.

[32] K. Matthews, J. Schwartz, S. Cohen, T. Seeman, Diurnal cortisol decline is related to coronary calcification: CARDIA study, Psychosom. Med. 68 (2006) 657-661, https://doi.org/10.1097/01.psy.0000244071.42939.0e.

[33] S.E. Sephton, E. Lush, E.A. Dedert, A.R. Floyd, W.N. Rebholz, F.S. Dhabhar, D. Spiegel, P. Salmon, Diurnal cortisol rhythm as a predictor of lung cancer survival, Brain. Behav. Immun. 30 (2013) S163-S170, https://doi.org/10.1016/j. bbi.2012.07.019.

[34] C. Ladeira, S. Viegas, M. Pádua, M. Gomes, E. Carolino, M.C. Gomes, M. Brito, Assessment of genotoxic effects in nurses handling cytostatic drugs, J. Toxicol. Environ. Heal. - Part A Curr. Issues 77 (2014) 879-887, https://doi.org/10.1080/ 15287394.2014.910158.

[35] I. Bortolotto, A.P.S. Brum, L.M. De Souza, C. Trindade, T.N. Guecheva, F.M. Luiz, A.L.L. De Paula-Ramos, A.R. Consiglio, DNA damage evaluation in a nursing team occupationally exposed to ionizing radiation Brazilian, J. Radiat. Sci. 3 (2015), https://doi.org/10.15392/bjrs.v3i1.82.

[36] A.R. Collins, A.A. Oscoz, G. Brunborg, I. Gaivão, L. Giovannelli, M. Kruszewski, C. C. Smith, R. Stetina, The comet assay: topical issues, Mutagenesis 23 (2008) 143-151, https://doi.org/10.1093/mutage/gem051.

[37] N.P. Singh, M.T. McCoy, R.R. Tice, E.L. Schneider, A simple technique for quantitation of low levels of DNA damage in individual cells, Exp. Cell Res. 175 (1988) 184-191, https://doi.org/10.1016/0014-4827(88)90265-0.

[38] D.W. Fairbairn, P.L. Olive, K.L. O'Neill, The comet assay: a comprehensive review, Mutat. Res. 339 (1995) 37-59, https://doi.org/10.1016/0165-1110(94)00013-3.

[39] A. Azqueta, S.A.S. Langie, E. Boutet-Robinet, S. Duthie, C. Ladeira, P. Møller, A. R. Collins, R.W.L. Godschalk, DNA repair as a human biomonitoring tool: comet 
assay approaches, Mutat. Res. - Rev. Mutat. Res. 781 (2019) 71-87, https://doi. org/10.1016/j.mrrev.2019.03.002.

[40] A.R. Collins, The comet assay for dna damage and repair: principles, applications, and limitations, Mol. Biotechnol. 26 (2004) 249-261, https://doi.org/10.1385/ MB:26:3:249.

[41] M. Fenech, W.P. Chang, M. Kirsch-Volders, N. Holland, S. Bonassi, E. Zeiger, M. Hu, Project, HUMN project: detailed description of the scoring criteria for the cytokinesis-block micronucleus assay using isolated human lymphocyte cultures, Mutat. Res. 534 (2003) 65-75, https://doi.org/10.1016/s1383-5718(02)00249-8.

[42] M. Fenech, A.A. Morley, Measurement of micronuclei in lymphocytes, Mutat. Res. 147 (1985) 29-36, https://doi.org/10.1016/0165-1161(85)90015-9.

[43] M. Fenech, Cytokinesis-block micronucleus cytome assay, Nat. Protoc. 2 (2007) 1084-1104, https://doi.org/10.1038/nprot.2007.77.

[44] E. Strauss, E.M.S. Sherman, O. Spreen, O. Spreen, A Compendium of Neuropsychological Tests: Administration, Norms, and Commentary, Oxford University Press, 2006.

[45] J.A. Alvarez, E. Emory, Executive function and the frontal lobes: a meta-analytic review, Neuropsychol. Rev. 16 (2006) 17-42, https://doi.org/10.1007/s11065006-9002-X.

[46] W. Van der Elst, M.P.J. Van Boxtel, G.J.P. Van Breukelen, J. Jolles, The stroop color-word test, Assessment 13 (2006) 62-79, https://doi.org/10.1177/ 1073191105283427.

[47] C.M. Macleod, Psychological bulletin: half a century of research on the stroop effect: an integrative review, Psychol. Assoc. 109 (1991) 199L.

[48] M.H. Agnoletto, T.N. Guecheva, F. Dondé, A.F. de Oliveira, F. Franke, C. Cassini, M. Salvador, J.A.P. Henriques, J. Saffi, Association of low repair efficiency with high hormone receptors expression and SOD activity in breast cancer patients, clin. Biochem. 40 (2007) 1252-1258, https://doi.org/10.1016/j clinbiochem.2007.08.017.

[49] C. Cassini, C. Calloni, G. Bortolini, S.C. Garcia, M.A. Dornelles, J.A.P. Henriques, B. Erdtmann, M. Salvador, Occupational risk assessment of oxidative stress and genotoxicity in workers exposed to paints during a working week, Int. J. Occup. Med. Environ. Health 24 (3) (2011) 308-319, https://doi.org/10.2478/s13382011-0030-2.

[50] H. Selye, The general adaptation syndrome and the diseases of adaptation, J. Allergy (Cairo) 17 (1946) 231.

[51] B.S. McEwen, Stressed or stressed out: What is the difference? J. Psychiatry Neurosci. 30 (2005) 315-318.

[52] K.E. Hannibal, M.D. Bishop, Chronic stress, cortisol dysfunction, and pain: a psychoneuroendocrine rationale for stress management in pain rehabilitation, Phys. Ther. 94 (12) (2014) 1816-1825, https://doi.org/10.2522/ptj.20130597.

[53] S.S. Dickerson, M.E. Kemeny, Acute stressors and cortisol responses: a theoretical integration and synthesis of laboratory research, Psychol. Bull. 130 (2004) 355-391, https://doi.org/10.1037/0033-2909.130.3.355.

[54] C. Kirschbaum, K.-M. Pirke, D.H. Hellhammer, The 'Trier Social Stress Test' - a tool for investigating psychobiological stress responses in a laboratory setting, Neuropsychobiology 28 (1993) 76-81, https://doi.org/10.1159/000119004.

[55] B.M. Kudielka, S. Wüst, Human models in acute and chronic stress: assessing determinants of individual hypothalamus-pituitary-adrenal axis activity and reactivity, Stress 13 (2010) 1-14, https://doi.org/10.3109/10253890902874913.

[56] N.O. Dmitrieva, D.M. Almeida, J. Dmitrieva, E. Loken, C.F. Pieper, A day-centered approach to modeling cortisol: Diurnal cortisol profiles and their associations among U.S. adults, Psychoneuroendocrinology. 38 (2013) 2354-2365, https://doi. org/10.1016/j.psyneuen.2013.05.003.

[57] Ş. Şimşek, T. Yüksel, İ. Kaplan, C. Uysal, H. Aktaş, The levels of cortisol and oxidative stress and DNA damage in child and adolescent victims of sexual abuse with or without post-traumatic stress disorder, Psychiatry Investig. 13 (2016) 616-621, https://doi.org/10.4306/pi.2016.13.6.616.

[58] G.J. Elder, M.A. Wetherell, N.L. Barclay, J.G. Ellis, The cortisol awakening response - applications and implications for sleep medicine Sleep, Med. Rev. 18 (2014) 215-224, https://doi.org/10.1016/j.smrv.2013.05.001.

[59] T. Lindahl, D.E. Barnes, Repair of endogenous DNA damage cold spring harb, Symp. Quant. Biol. 65 (2000) 127-133, https://doi.org/10.1101/sqb.2000.65.127.

[60] S.M. Toprani, B. Das, Role of base excision repair genes and proteins in gammairradiated resting human peripheral blood mononuclear cells, Mutagenesis 30 (2015) 247-261, https://doi.org/10.1093/mutage/geu065.
[61] M.H.L. Green, A.P.W. Waugh, J.E. Lowe, S.A. Harcourt, P.H. Clingen, J. Cole, C. F. Arlett, Protective effect of deoxyribonucleosides on UV-irradiated human peripheral blood T-lymphocytes: possibilities for the selective killing of either cycling or non-cycling cells, Mutat. Res. - Fundam. Mol. Mech. Mutagen. 350 (1996) 239-246, https://doi.org/10.1016/0027-5107(95)00110-7.

[62] A.L.G. da Silva, H.T. da Rosa, E. Bender, P.R. da Rosa, M. Salvador, C.F. Charlier, D. J. Moura, A.R. de M. Valim, T.N. Guecheva, J.A.P. Henriques, Effect of physical exercise on the level of dna damage in chronic obstructive pulmonary disease patients ISRN, Pulmonol 2013 (2013) 1-8, https://doi.org/10.1155/2013/ 907520.

[63] E. Van Cauter, R. Leproult, D.J. Kupfer, Effects of gender and age on the levels and circadian rhythmicity of plasma cortisol, J. Clin. Endocrinol. Metab. 81 (1996) 2468-2473, https://doi.org/10.1210/jcem.81.7.8675562.

[64] W.C. Engeland, M.M. Arnhold, Neural circuitry in the regulation of adrenal corticosterone rhythmicity, Endocrine 28 (2005) 325-332, https://doi.org/ 10.1385/ENDO:28:3:325.

[65] E. Young, J. Abelson, S. Lightman, Cortisol pulsatility and its role in stress regulation and health Front, Neuroendocrinol. 25 (2004) 69-76, https://doi.org/ 10.1016/j.yfrne.2004.07.001.

[66] S.L. Andersen, M.H. Teicher, Delayed effects of early stress on hippocampal development, Neuropsychopharmacology 29 (2004) 1988-1993, https://doi.org/ 10.1038/sj.npp.1300528.

[67] J.D. Bremner, Functional neuroanatomical correlates of traumatic stress revisited 7 years later, this time with data, Psychopharmacol. Bull. 37 (2003) 6-25.

[68] J.P. Herman, M.M. Ostrander, N.K. Mueller, H. Figueiredo, Limbic system mechanisms of stress regulation: hypothalamo-pituitary-adrenocortical axis, Prog. Neuro-Psychopharmacol. Biol. Psychiatry 29 (2005) 1201-1213, https://doi.org/ 10.1016/j.pnpbp.2005.08.006.

[69] P.D. Evans, C. Fredhoi, C. Loveday, F. Hucklebridge, E. Aitchison, D. Forte, A. Clow, The diurnal cortisol cycle and cognitive performance in the healthy old, Int. J. Psychophysiol. 79 (2011) 371-377, https://doi.org/10.1016/j. ijpsycho.2010.12.006.

[70] G.E. Ennis, S.D. Moffat, C. Hertzog, Spontaneous physical activity defends against, obesity Physiol. Behav. 176 (2016) 139-148, https://doi.org/10.1016/j. physbeh.2017.03.040.

[71] T.W. Buchanan, S. Kern, J.S. Allen, D. Tranel, C. Kirschbaum, Circadian regulation of cortisol after hippocampal damage in humans, Biol. Psychiatry 56 (2004) 651-656, https://doi.org/10.1016/j.biopsych.2004.08.014.

[72] R.P. Juster, S. Sindi, M.F. Marin, A. Perna, A. Hashemi, J.C. Pruessner, S.J. Lupien, A clinical allostatic load index is associated with burnout symptoms and hypocortisolemic profiles in healthy workers, Psychoneuroendocrinology. 36 (2011) 797-805, https://doi.org/10.1016/j.psyneuen.2010.11.001.

[73] A.M.M. de Magalhães, G.M.S.S. de Moura, S.S. Pasin, L.B. Funcke, B.M. Pardal, A. Kreling, Processos de medicação, carga de trabalho e a segurança do paciente em unidades de internação/ Medication processes, workload and patient safety in inpatient units, Rev. Esc. Enferm. 49 (2015) 43-50, https://doi.org/10.1590/ S0080-623420150000700007.

[74] S.J. Johnson, E.M. O'Connor, S. Jacobs, K. Hassell, D.M. Ashcroft, The relationships among work stress, strain and self-reported errors in UK community pharmacy, Res. Soc. Adm. Pharm. 10 (2014) 885-895, https://doi.org/10.1016/j. sapharm.2013.12.003.

[75] E.J.K. Wadsworth, S.A. Simpson, S.C. Moss, A.P. Smith, The Bristol Stress and Health Study: accidents, minor injuries and cognitive failures at work, Occup. Med. (Chic. Ill). 53 (2003) 392-397, https://doi.org/10.1093/occmed/kqg088.

[76] M.R. Seleghim, M.A. Mombelli, M.L.F. de Oliveira, M.A.P. Waidman, S.S. Marcon, Sintomas de estresse em trabalhadoras de enfermagem de uma unidade de pronto socorro, Rev. Gaúcha Enferm. 33 (2012) 165-173, https://doi.org/10.1590/ S1983-14472012000300022.

[77] J.E. Sheridan, D.J. Vredenburgh, Usefulness of leadership behavior and social power variables in predicting job tension, performance, and turnover of nursing employees, J. Appl. Psychol. 63 (1978) 89-95, https://doi.org/10.1037/00219010.63.1.89.

[78] A. Wojda, E. Ziętkiewicz, M. Witt, Effects of age and gender on micronucleus and chromosome nondisjunction frequencies in centenarians and younger subjects, Mutagenesis. 22 (2007) 195-200, https://doi.org/10.1093/mutage/gem002.

[79] A.J. Tomiyama, Stress and obesity, Annu. Rev. Psychol. 70 (2019) 703-718, https://doi.org/10.1146/annurev-psych-010418-102936. 